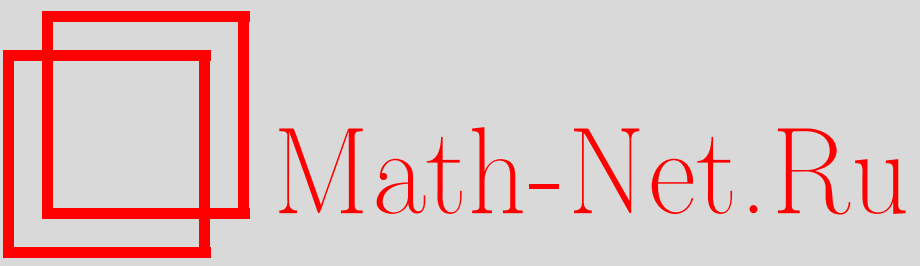

О. В. Висков, В. А. Ильин, Л. Д. Кудрявцев, Е. И. Моисеев, С. М. Никольский, Анатолий Платонович Прудников (некролог), УМН, 1999, том 54, выпуск 4, $147-$ 148

DOI: https://doi.org/10.4213/rm199

Использование Общероссийского математического портала Math-Net.Ru подразумевает, что вы прочитали и согласны с пользовательским соглашением

http://www.mathnet.ru/rus/agreement

Параметры загрузки:

IP : 54.80 .97 .219

26 апреля 2023 г., 16:23:34 


\section{АНАТОЛИЙ ПЛАТОНОВИЧ ПРУДНИКОВ}

10 января 1999 года скончался Анатолий Платонович Прудников.

Анатолий Платонович родился 14 января 1927 года в Ульяновске. В 1944 году он, окончив в Самаре среднюю школу, поступил в Куйбышевский авиационный институт. В 1947 году переводится на физико-математический факультет Куйбышевского педагогического института, который окончил в 1947 году. С 1949 по 1952 год работал ассистентом кафедры высшей математики Куйбышевского педагогического института и учителем средней школы. В 1952 году поступил в аспирантуру этого института по специальности "высшая математика" и в феврале 1954 года был командирован в Институт точной механики и вычислительной техники Академии наук СССР, где его научным руководителем стал профессор В.А. Диткин. С 1955 года и до последних дней А.П. Прудников работал в Выгислительном центре $\mathrm{AH} \mathrm{CCCP}$, где он прошел путь от младшего научного сотрудника до доктора наук, профессора, заведующего отделом. В 1957 году Анатолий Пла-

тонович защитил кандидатскую диссертацию "Аналитические исследования процессов теплои массообмена", а в 1968 году - докторскую диссертацию "Об одном классе интегралњных преобразований типа Вольтерра и некоторых обобщениях операционного исчисления".

Научные интересы Анатолия Платоновича сформировались в области прикладной математики под влиянием В. А. Диткина. В результате совместной деятельности в 1958 году вышла в свет их первая монография, посвященная операционному исчислению по двум переменным, сыгравшая важную роль в развитии этого направления.

В области классической проблематики операционного исчисления А. П. Прудниковым построена теория некоторых классов дифференциальных, в том числе обобщенных бесселевых, и разностных операторов, сушественно расширившая круг задач, разрешимых операторными методами. Эти исследования получили широкое признание как в СССР, так и за рубежом, и заслуженно были отмечены Государственной премией СССР в 1978 году, полученной А. П. Прудниковым совместно с В.А. Диткиным и В.П. Масловым.

Международную известность получили работы Анатолия Платоновича по интегральным преобразованиям и специальным функциям, подытоженные в созданном им совместно со своими учениками фундаментальном руководстве "Интегралы и ряды" в пяти томах обшим объемом около 400 печатных листов, значительно перекрывающем известный в этой области цикл книг Бейтмана-Эрдейи. В совокупности эти пять томов являются незаменимым пособием для каждого исследователя и специалиста - математика, физика, инженера, применяющего методы математического анализа. 
А. П. Прудникову принадлежат резултаты по разработке аналитических и численных методов решения граничных задач для уравнения Лапласа в областях специального вида, к которым приводит оптимизация ряда конкретных физических задач (оптимизация профилей проката, крутильные колебания валов, кручение призматических стержней со сложным профилем поперечного сечения). Анатолий Платонович являлся руководителем и исполнителем проводимых в Государственном научно-исследовательском испытательном институте авиационной и космической медицины МО РФ работ в области медицинской информатики. В результате создан комплекс математических моделей, алгоритмов, программ и номограмм, предназначенных для применения в медицинских исследованиях и позволяющих проводить оценку иерархических уровней профессионального здоровья летного состава и оценку уровней радиационного и электромагнитного загрязнения окружающей среды.

А. П. Прудников - автор и соавтор около 100 научных работ, в том числе 10 книг, переизданных в Англии, Германии, Польше, Франции, США, Японии. Среди его учеников 15 кандидатов и два доктора наук.

Анатолий Платонович отдавал много сил административной и общественной деятельности. С 1975 по 1987 год работал заместителем начальника отдела естественных наук ВАК СССР, продолжая по совместительству работу в ВЦ РАН. Это было сложное время перестройки системы аттестации научно-педагогических кадров и обостренной борьбы математических школ. На этой работе он в полной мере проявил сочетание принципиальности с доброжелательностью и порядочностью. В последнее время он возглавлял Экспертный Совет ВАК России по математике и механике.

А.П. Прудников - основатель и до последних дней жизни главный редактор международного журнала "Integral Transforms and Special Functions", он - редактор международной серии монографий "Analytical Methods and Special Functions" (Gordon \& Breach).

Анатолий Платонович был всесторонне образованным человеком. Он проявлял интерес к музыке, разбирался в живописи, любил поэзию, классическую литературу, читал и сочинял стихи. Особенно он любил и ценил общение с интересными людьми.

Память об Анатолии Платоновиче навсегда сохранится в наших сердцах.

О. В. Висков, В.И. Ильин, Л. Д. Кудрявцев, Е.И. Моисеев, С. М. Никольский 